Rev. Latinoam. Psicopat. Fund., São Paulo, v. 11, n. 3, p. 506-508, setembro 2008

Ensaios - O que psiquiatras fazem

Carol Sonenreich e Giordano Estevão

São Paulo: Casa Editorial Lemos, 2007, 368 págs.

\title{
O que psiquiatras fazem
}

Durval Mazzei Nogueira Filho

Há uma novidade interessante no mercado editorial, voltado ao público "psi": O que psiquiatras fazem. É o último livro do professor Carol Sonenreich, escrito com a colaboração do professor Giordano Estevão e publicado pela Casa Editorial Lemos. E este livro é um alento, uma esperança e uma demonstração de inteligência. Estes termos, bons para uma hagiografia, não são excessivos e não são bajuladores. Pelo menos àqueles psiquiatras que não estão contentes com o rumo contemporâneo da psiquiatria.

Descontentamento que não é dirigido somente a aspectos menores da psiquiatria, mas ao núcleo ideológico no sentido de Destutt de Tracy - que orienta o pensamento psiquiátrico contemporâneo.

Um exemplo. Recentemente surgiu na imprensa leiga e especializada alertas ao excesso de diagnósticos e ao excesso e, talvez, inútil uso de antidepressivos. As publicações colocaram este grupo de medicamentos na berlinda. Os antidepressivos foram considerados indutores 
de suicídio tão eficazes quanto o placebo na maioria das condições clínicas aonde é indicado.

Qualquer sujeito um pouquinho arguto percebe que tais conclusões são amplamente contraditórias. Um fármaco tão efetivo quanto o placebo não pode exercer um efeito tão dramático - indução ao suicídio - naqueles que o tomam. Trata-se, portanto, de uma equação absurda.

Como se explica este resultado? Explicação delicada, pois os autores das pesquisas lançam mão do mesmo estilo metodológico - o verificacionismo empírico, de fundamentação ateorética - que, não obstante a crítica epistemológica à garantia do conhecimento e saber produzido por este meio, define o coração e a mente, o trunfo ideológico, de boa parte da comunidade psiquiátrica. É o método para determinar tanto a evidência da eficiência dos tratamentos quanto da existência de entidades clínicas específicas. E este método não evita que conclusão disparatada como as referidas acima se estabeleçam.

Não repetir este esquema é o bálsamo que o livro dos professores Carol e Giordano traz. Os autores utilizam as pesquisas - o livro, aliás, é rico em citações atuais, mas as utilizam como instrumentos ao pensar, como cooperação ao discurso médico e não como revelação de fatos discretos existentes na natureza.

O livro, portanto, é uma demonstração que o psiquiatra pode, e deve, perguntar, teorizar, renovar para além de um punhado de evidências ilusórias nas quais alguns vêem a maturidade da psiquiatria. Não é como os tratados recomendados a jovens residentes que não vão além de repetir a lógica dos manuais diagnósticos em voga.

Preparem-se, então, para uma série de ensaios que discutem desde o fundamento da psiquiatria, fundamento que torna a perspectiva médica diante do sofrimento psíquico legítima, passa por oportunas discussões a propósito de grandes capítulos presentes em qualquer livro-texto para interessados em psiquiatria (delírios, dependências, demências, depressão). E, como não poderia deixar de constar, os ensaios ainda discutem a viabilidade, os limites e as virtudes, do furor avaliador e mensurador presente no núcleo ideológico da psiquiatria. Os capítulos "Avaliações" e "Subjetividade e quantificação" esclarecem o quanto o pensamento e o raciocínio, a partir de bases teóricas consistentes, são, ao contrário do sonho de sustentar a psiquiatria em um curto-circuito direto, ateorético, com a natureza, necessários ao bem correr da atividade do psiquiatra.

Além destes tópicos, o leitor ainda encontrará boas surpresas nas discussões sobre psicoterapia, psicanálise, neurociência e sobre os sistemas classificatórios oficiais.

A propósito das neurociências, é bem claro que os autores esposam uma perspectiva que não resume a neurociência à procura de estruturas cerebrais fi- 
xas determinadas por constelações genéticas também fixas. São hábeis em construir raciocínios que admitem um cérebro plenamente subvertido pela cultura, pela linguagem e pelas vivências, o que contempla um órgão, antes de tudo, dinâmico e sui generis.

Enfim, é um livro que mostra o quanto a psiquiatria tem a oferecer à saúde da população. É um livro que declara "morte ao estereótipo" e não "morte à inteligência" e abre uma perspectiva que rompe a estreita bitola que os partidários de uma concepção unitária da ciência, em conluio com laboratórios farmacêuticos e empresários públicos e privados da medicina, pretenderam e pretendem regularizar e monitorar o fazer do psiquiatra.

Não repetir é um prazer e uma obrigação.

\section{Durval Mazzei Nogueira Filho}

Mestre em Psiquiatria pelo Instituto de Assistência Médica ao Servidor Público Estadual, do Hospital do Servidor Público (São Paulo, SP, Brasil); psicanalista; membro da seção São Paulo da Escola Brasileira de Psicanálise (São Paulo, SP, Brasil); membro do departamento "Formação em Psicanálise" do Instituto Sedes Sapientiae (São Paulo, SP, Brasil).

Rua Alm. Pereira Guimarães, 298

01250-000 São Paulo, SP, Brasil

Fone: (11) 3862-5716

e-mail:dr.durval@uol.com.br 